\title{
АКТУАЛЬНІ ПРОБЛЕМИ ВИБОРЧОГО ПРОЦЕСУ В УКРАЇНІ
} ACTUAL PROBLEMS OF THE ELECTION PROCESS IN UKRAINE

\author{
Ларченко М.О., к.ю.н., доцент, \\ доцент кафедри політології, права та філософії \\ Ніжинський державний університет імені Миколи Гоголя
}

\begin{abstract}
У статті досліджено ряд питань, пов'язаних з актуальними проблемами виборчого процесу в Україні. Розглядувані аспекти нормативно-правового регулювання з'явились з прийняттям Виборчого кодексу України (далі - ВКУ). Особлива увага приділена місцевим виборам, бо саме вони були проведені в Україні за новим законодавством. Ключові проблеми місцевих виборів наступні: 1) можливість та потреба перевірки даних, які подаються кандидатами для реєстрації; 2) процедура розподілу керівних посад у дільничних виборчих комісіях; 3) обрахування виборчої квоти та розподіл мандатів за пропорційною виборчою системою.

Зокрема, розглянуто конкретні судові рішення з питань оскарження фактів реєстрації територіальними виборчими комісіями кандидатів на посади міських голів. Оскарження мали місце через повідомлення кандидатами у своїй автобіографії відомостей, які, на думку позивачів, не відповідають дійсності. Ключовим моментом $€$ те, що судові органи наголошують на системному тлумаченні терміна «обставини, які позбавляють особу, висунуту кандидатом, права бути обраною». Идеться лише про ті вимоги, яким повинна відповідати особа, яка балотується (а саме: вік, громадянство, дієздатність, відсутність судимості тощо) і в разі недотримання яких, особа втрачає право бути обраною. Надана законодавча пропозиція щодо внесення відповідних змін до ВКУ.

Для парламентських та президентських виборів актуальною залишається проблема удосконалення виборчої системи з огляду на передовий європейський досвід. Україна наразі відмовилася від мажоритарної складової виборчої системи на парламентських виборах, що є позитивним кроком і сприятиме зближенню з ЄС

Спільними проблемами для всіх типів виборів в Україні залишаються питання оскарження різноманітних процедур виборчого процесу, а також невідворотності притягнення до адміністративної або кримінальної відповідальності порушників виборчого процесу. Для подальшого удосконалення виборчого законодавства, важливо, щоб Виборчий кодекс абсолютно однозначно визначав усі дозволи, заборони та обмеження в процесі підготовки та проведення виборчої кампанії. Від цього значною мірою залежить наявність або відсут-
\end{abstract} ність використання адміністративного ресурсу, підкупу виборців, нерівності можливостей суб'єктів виборчого процесу.

Ключові слова: виборчий процес, Виборчий кодекс України, місцеві вибори, парламентські вибори, мажоритарна виборча система, пропорційна виборча система.

The article examines aspects related to current issues of the election process in Ukraine. The problems of normative-legal regulation considered in the article appeared with the adoption of the Electoral Code of Ukraine. Particular attention is paid to local elections, because they were held in Ukraine under the new legislation. The key problems of local elections are the following: 1) the possibility and need to verify the data submitted by candidates for registration; 2) the procedure for the distribution of managerial positions in precinct election commissions; 3) calculation of the electoral quota and distribution of seats according to the proportional electoral system.

In particular, specific court decisions on appeals against the registration of candidates for mayors by territorial election commissions were considered. The appeals took place because the candidates provided information in their CVs which, in the opinion of the plaintiffs, did not correspond to reality. The key point is that the judiciary emphasizes a comprehensive interpretation of the term "circumstances that deprive a nominee of the right to be elected". These are only the requirements that a candidate must meet (namely: age, citizenship, legal capacity, no criminal record, etc.) and in case of non-compliance with which, the person loses the right to be elected. A legislative proposal to amend the Electoral Code of Ukraine has been submitted.

For the parliamentary and presidential elections in Ukraine, the problem of improving the electoral system in view of the best European experience remains relevant. Ukraine has now abandoned the majority component of the electoral system in the parliamentary elections, which is a positive step and will promote rapprochement with the EU.

Common problems for all types of elections in Ukraine are the issues of appealing against various procedures of the election process, as well as the inevitability of bringing to administrative or criminal responsibility violators of the election process. In order to further improve the election legislation, it is important that the Electoral Code clearly defines all permits, prohibitions and restrictions in the process of preparation and conduct of the election campaign. The presence or absence of the use of administrative resources, voter bribery, inequality of opportunities for the subjects of the election process largely depends on this.

Key words: electoral process, Electoral Code of Ukraine, local elections, parliamentary elections, majority electoral system, proportional electoral system.

Постановка проблеми. 19 грудня 2019 року було прийнято Виборчий кодекс України [1], який став першим в Україні кодифікованим актом, де вміщено всі ключові моменти організації та проведення виборчого процесу.

Вибори в Україні є основною формою народного волевиявлення, способом безпосереднього здійснення влади Українським народом. Згідно з Виборчим кодексом вибори в Україні є вільними й відбуваються на основі загального, рівного та прямого виборчого права шляхом таємного голосування. Крім Конституції України та Виборчого кодексу підготовка та проведення виборів регулюється також законами України «Про Центральну виборчу комісію», «Про Державний реєстр виборців» тощо.

В Україні проводяться наступні типи виборів: вибори Президента України, вибори народних депутатів України, місцеві вибори.

Виборчий процес, на думку законодавця, - це здійснення суб'єктами (впродовж встановленого Кодексом періоду) виборчих процедур, визначеними ст. 22 Виборчого кодексу, пов'язаних із підготовкою і проведенням відповідних виборів, встановленням та офіційним оголошенням (офіційним оприлюдненням) їх результатів.

3 часів отримання Україною незалежності фактично склалась ситуація, коли майже кожні чергові або позачергові вибори відбувались за новим виборчим законом або попереднім, куди вносились істотні зміни. Часто такі закони приймались зі значними перекосами в бік інтересів тієї чи іншої правлячої еліти. Така ситуація не додавала ефективності в роботі обраних у такий спосіб органів, сприяла втраті довіри населення до влади в цілому, спровокувала ряд кризових політичних ситуацій в державі. Тому, безумовно, введення в дію єдиного кодифікованого акту, де спостерігається систематизація та узагальнення ключових виборчих процедур, є позитивним кроком на шляху розбудови правової демократичної України. 
Аналіз останніх досліджень і публікацій. На думку вітчизняних дослідників, вибори виступають показником рівня демократичності у державі та рівня довіри громадян до влади. Саме під час проведення виборів $\epsilon$ можливість побачити наявні суспільно-політичні проблеми, характер боротьби між різними групами впливу, недоліки нормативно-правової бази тощо. Оскільки виборчий процес чинить вплив на формування влади та подальшого політичного курсу в країні (або на певній території за умов проведення місцевих виборів), то це питання потребує пильної уваги з боку дослідників, політиків, пересічних громадян, а найголовніше - представників органів влади усіх рівнів [2].

А.І. Кормич, Л.І. Кормич слушно зауважують, що загальна характеристика цього процесу потребує дослідження поведінки основних суб'єктів, змін правової регламентації, впровадження нових форм та методів діяльності, факторів впливу на настрої та ряду інших важливих складових виборчого процесу [3].

Закономірно, що більшість фахівців 3 конституційного права та процесу тривалий час наголошували на необхідності прийняття сталого уніфікованого для всіх типів виборів, кодифікованого нормативного акту. Так, В.А. Стукаленко вважає, що для забезпечення стабільності у виборчому законодавстві та подальшої гармонізації, повинні докладатися зусилля для завершення виборчої реформи. Тобто, зміна виборчого законодавства повинна здійснюватися заздалегідь до проведення наступних виборів, також необхідно встановлювати запобіжники проти внесення змін до законодавства перед виборами [4].

Наразі лише місцеві вибори 25 жовтня 2020 року відбулись за новим Виборчим кодексом. Саме цей процес зробив помітними ряд недоліків чинного виборчого законодавства, зокрема, щодо цього типу виборів. Ці моменти знов потребують уваги науковців 3 метою удосконалення нормативноправового регулювання виборчого процесу в Україні.

Мета статті - висвітлення актуальних проблем виборчого процесу в Україні в умовах дії нового виборчого Закону; аналіз судової практики та обгрунтування пропозицій щодо удосконалення нормативно-правового регулювання виборчого процесу.

Виклад основного матеріалу. За Виборчим кодексом значно обмежені повноваження територіальних виборчих комісій (далі - ТВК) у питаннях перевірки даних, які подаються кандидатами для реєстрації; щодо розгляду скарг суб'єктів виборчого процесу тощо. Так, в кількох регіонах України під час виборчого процесу розгорталися конфліктні ситуації, які стосувалися процедури реєстрації кандидатів на виборах міських (сільських, селищних) голів. Узагальнене вирішення цих конфліктів може бути зведене до аналізу наступних норм виборчого закону та підзаконних актів.

По-перше, відповідно до абз. 1 ч. 4 ст. 65 ВКУ та п. п. 3 п. 3.1. Порядку розгляду скарг виборчими комісіями з виборів Президента України, народних депутатів України, місцевих виборів [5], до територіальної виборчої комісії, яка встановлює результати відповідних місцевих виборів оскаржуються:

- рішення, дії чи бездіяльність територіальної виборчої комісії нижчого рівня, яка встановлює підсумки голосування з відповідних місцевих виборів;

- рішення, дії чи бездіяльність дільничної виборчо комісії, яка забезпечує організацію і проведення відповідних місцевих виборів (у разі, якщо підсумки голосування з відповідних місцевих виборів не встановлюються).

Відповідно до п. 3.4. Порядку розгляду скарг, виключно до суду, в порядку, встановленому Кодексом адміністративного судочинства України, оскаржуються дії та бездіяльність кандидата [5].

Враховуючи вищезазначене, тепер ТВК взагалі не $\epsilon$ належним суб'єктом розгляду скарги будь-якого кандидата на дії іншого кандидата на виборну посаду.
По-друге, стаття 231 ВКУ містить вичерпний перелік підстав для прийняття ТВК рішення про скасування реєстрації кандидата, вже зареєстрованого у виборчому окрузі. У цьому переліку відсутня така підстава як: «внесення недостовірних даних до автобіографії кандидата».

Так, відповідно до п. 8 ч. 1 ст. 231 ВКУ до підстав для прийняття рішення про скасування реєстрації, зокрема, належить виявлення інших обставин, які позбавляють особу, висунуту кандидатом на посаду міського голови, права бути обраною міським головою.

Неправдиві дані, внесені кандидатом до автобіографії, не $\epsilon$ обставинами, які позбавляють особу, висунуту кандидатом, права бути обраним міським головою.

Обставини, які позбавляють особу бути кандидатом, перелічені в ч. 2 ст. 193 Виборчого кодексу України. До таких належать: судимість за вчинення тяжкого або особливо тяжкого злочину, кримінального правопорушення проти виборчих прав громадян чи корупційного кримінального правопорушення, якщо ця судимість не погашена або не знята в установленому законом порядку.

Цей перелік $€$ вичерпним та не допускає включення до нього інших підстав.

Втім, згідно з п. 6.4 Порядку розгляду скарг виборчими комісіями з виборів Президента України, народних депутатів України, місцевих виборів, затвердженим Постановою ЦВК № 192 від 21.08.2020 року суб’єкт звернення може у скарзі заявляти вимоги про:

1) визнання рішення суб'єкта оскарження таким, що не відповідає вимогам законодавства (є протиправним), порушує виборчі права громадян, права та законні інтереси суб'єкта виборчого процесу та його скасування;

2) визнання дій суб'єкта оскарження такими, що не відповідають вимогам законодавства (є протиправними), порушують виборчі права громадян, права та законні інтереси суб'єкта виборчого процесу та зобов'язання утриматися від вчинення певних дій;

3) визнання бездіяльності суб'єкта оскарження такою, що не відповідає вимогам законодавства (є протиправною), порушує виборчі права громадян, права та законні інтереси суб'єкта виборчого процесу та зобов'язання вчинити певні дії;

4) поновлення в інший спосіб, що не суперечить Кодексу, порушених виборчих прав громадян, прав та законних інтересів суб'єкта виборчого процесу [5].

По-третє, відомості про місце роботи і так само про місце проживання ТВК отримує 3 документів, що їх заповнює сам кандидат, і він же несе відповідальність за ї достовірність згідно з ч. 4 ст. 224 Виборчого кодексу України. ТВК не уповноважена перевіряти ці відомості, проводити розслідування тощо. Запити до офіційних установ можуть надсилатись 3 метою встановлення офіційних відомостей, що конкретно в законі зазначені як такі, що унеможливлюють реєстрацію особи або викликають необхідність скасування цієї реєстрації. Йдеться про наявність судимості, перетин кордону тощо. Відомості щодо місця роботи та адреси проживання самі по собі не позбавляють особу права бути обраним міським головою, і навіть у разі їх неправдивості не може бути підставою для зняття 3 реєстрації.

Враховуючи вищезазначене, ТВК не має підстав для скасування реєстрації кандидата у разі подання ним у біографії неправдивих відомостей, оскільки це не передбачено Виборчим кодексом України.

Наведена позиція законодавця безумовно є виправданою, виходячи з того, що ТВК не $є$ слідчим органом та не має відповідних ресурсів і можливостей, щоб встановлювати ті чи інші, другорядні для виборчого процесу, факти. Аналогічна думка висловлюється в ряді рішень Адміністративних судів за 2020 рік [6; 7].

Зокрема, Чернігівський окружний адміністративний суд у своєму Рішенні зазначає наступне: «Відповідно до 
ч. 1-2 ст. 206 ВКУ, територіальна виборча комісія на період здійснення своїх повноважень забезпечує організацію і проведення місцевих виборів у межах повноважень та в порядку, передбачених цим Кодексом та законами України». Таким чином, з системного аналізу вищезазначених норм (п. 8 ч. 1 ст. 231 , ст. 193, п. 1 ч. 2 ст. 230 , ч. 1-4 ст. 224 ВКУ М.Л.) вбачається, що вжитий у п. 8 ч. 1 ст. 231 ВКУ термін «обставини, які позбавляють особу, висунуту кандидатом, права бути обраною» стосуються тих вимог, яким повинна відповідати особа, яка балотується (а саме: вимог щодо віку, громадянства, дієздатності та відсутності судимості тощо) і в разі недотримання яких, особа втрачає право бути обраною [6].

На нашу думку, законодавцю варто було б конкретизувати це положення в Кодексі наступним чином: обставинами, які позбавляють особу, зареєстровану кандидатом в депутати, на посаду сільського, селищного, міського голови $є$ повідомлення нею неправдивих відомостей щодо віку, громадянства, дієздатності та відсутності судимості; у разі встановлення факту подання неправдивих відомостей кандидатом до територіальної виборчої комісії, суд своїм рішенням скасовує реєстрацію кандидата. Відповідне рішення має бути прийняте не пізніше, ніж за 2 дні до дня голосування.

Також багато запитань на місцевих виборах в Україні викликає нинішня процедура розподілу керівних посад у дільничних виборчих дільницях (далі - ДВК) за принципом лотереї. Подекуди це призводило до зайняття одним суб' єктом подання керівних посад у всіх ДВК і отримання таким чином переважаючого контролю над виборчим процесом в місті або районі. Набагато краще себе зарекомендував, так званий, квотний принцип розподілу керівних посад, пропорційно до кількості поданих партійним осередком кандидатів.

Чергові вибори народних депутатів України, що врегульовані Книгою третьою Виборчого кодексу, мають відбутися в останню неділю жовтня 2024 року у зв'язку із закінченням останнього року повноважень Верховної Ради України. Згідно з Кодексом вони відбуватимуться на засадах пропорційної системи за єдиними списками кандидатів у депутати в загальнодержавному виборчому окрузі, з яких формуються регіональні виборчі списки кандидатів у депутати від партій (ст. 133 ВКУ).

Актуальною проблемою в площині законодавчого врегулювання парламентських виборів в Україні є втрата державою фактичного контролю над частиною території України у зв'язку з їі окупацією. В таких умовах проведення виборів на зазначених територіях $€$ або неможливим взагалі, або вкрай неефективним процесом 3 точки зору дотримання прав людини.

Принциповим рішенням законодавця щодо парламентських виборів $\epsilon$ відмова від мажоритарної системи. Дискусії щодо оптимальної схеми проведення парламентських виборів мають місце 3 часу проголошення незалежності України, бо в існуючих політичних реаліях обидві схеми несуть багато ризиків. Якщо основним недоліком мажоритарної системи $\epsilon$ використання в регіонах адмінресурсу, то противники пропорційної системи наголошують на формальному голосуванні виборцями за партію, виходячи з харизматичності ії лідера, без знайомства з усім списком кандидатів від партії.

Тривалий час парламентські вибори в Україні проводились за змішаною (мажоритарно-пропорційною) системою у співвідношенні 50\% / 50\%. Однак мажоритарна складова весь час була пов'язана зі зловживаннями, які починалися ще під час виборчої компанії, тому рішення про ліквідацію мажоритарної складової $\epsilon$ абсолютно виправданим.

Зокрема, у переважній більшості країн Свропейського Союзу парламентські вибори проводяться за пропорційними виборчими системами Це 18 держав 3 25. Мажо- ритарні ж системи застосовуються у тих випадках, коли кількість мандатів, які підлягають розподілу, мала і застосування пропорційної системи видається недоцільним.

Втім, у Франції та Великобританії склад нижніх палат парламенту повністю формується за мажоритарною системою. В Угорщині та Німеччині застосовуються змішані виборчі системи. Однак, по суті вони також є пропорційними.

Крім цього в законодавстві більшості країн СС передбачене врахування не лише партійних уподобань, але й рівня підтримки виборцями партійних кандидатів. Більшість країн мають відкриті списки кандидатів.

Переважно в країнах ЄС законодавчо встановлено такий механізм розподілу мандатів на парламентських та місцевих виборах, який сприяє в першу чергу найбільш популярним партіям. Винятки 3 цього правила у цих країнах встановлено лише для партій, які репрезентують інтереси національних меншин. У ряді країн Східної Європи 3 метою стабілізації партійної системи встановлено високі виборчі бар'єри для блоків.

Цікавим аспектом є те, що в таких країнах як Греція, Італія та Франція на місцевих виборах встановлено додаткові бонуси для тих партій, які набрали найбільшу кількість голосів. У такий спосіб вони одержують ще більше мандатів, ніж здобули б пропорційно до отриманої підтримки виборців. Однак, український законодавець саме під час законодавчого врегулювання розподілу мандатів на місцевих виборах пішов зворотнім шляхом: було встановлено порядок визначення виборчої квоти, за яким партії, що отримали найбільшу підтримку, отримають у пропорційному відношенні менше мандатів; а ті, що отримали мінімальну кількість голосів (ледве подолали прохідний бар'єр) отримують додатковий мандат за рахунок фактичних переможців.

Нелогічність такого підходу проявилася під час місцевих виборів у 2020 році в Україні. Через невелику кількість мандатів, що підлягають розподілу в місцевих радах (залежно від кількості виборців), кожен мандат має значення та вагу для місцевого партійного осередку.

Очевидно, що між вибором системи для парламентських і місцевих виборів існує певний взаємозв'язок. Найчастіше на місцевих виборах повторюється виборча система, що передбачена на парламентських, але у пристосованому та дещо модифікованому варіанті. Втім, у 8 країнах $\mathrm{CC} \mathrm{місцеві} \mathrm{виборчі} \mathrm{системи} \mathrm{істотно} \mathrm{відрізняються} \mathrm{від}$ виборчих систем на парламентських виборах.

Часто вирішальне значення для того, яку систему обирає законодавчий орган, має кількість виборців у межах адміністративної одиниці, які мають голосувати на місцевих виборах.

Що стосується президентських так званих мерських виборів, то вони, як правило, обираються шляхом непрямих виборів, що пов'язано із забезпеченням ефективності інституту політичної відповідальності за результати впровадження загальнодержавної політики на місцевому рівні. Мажоритарна система відносної більшості на прямих президентських виборах не застосовується взагалі, а на мерських виборах - дуже рідко.

Варто погодитись 3 думкою науковців, що порядок проведення, можливі загрози зловживань та порушень з боку усіх учасників процесу залежить від багатьох факторів. Серед них:

- усталеність політичної системи в країні;

- стабільність суспільно-політичних відносин;

- фундаментальність діючих законів;

- рівень організації виборчого процесу на усіх етапах;

- наявність високої політичної та правової культури у переважної більшості учасників (представників органів публічної влади, політичних діячів, політтехнологів, пересічних громадян-виборців тощо);

- імідж політичної еліти та громадська думка про неї [2]. 
В Україні всі ці фактори поки що залишаються на вкрай низькому рівні, але прийняття єдиного кодифікованого акту є важливим кроком, який сприятиме фундаментальності діючого виборчого законодавства.

Кримінальним кодексом України, Кодексом України про адміністративні правопорушення передбачено юридичну відповідальність за неправомірне втручання у виборчий процес з боку органів влади, суб'єктів виборчого процесу тощо. Втім, на практиці переважна більшість зловживань та відвертих маніпуляцій під час виборів залишаються безкарними. Причиною $є$, в першу чергу, той факт, що суспільна думка не виробила однозначного засудження таких дій, навіть відверто злочинні дії членів виборчих комісій сприймаються суспільством поблажливо. Крім цього, невідпрацьована також і практика покарання за неправомірне перешкоджання вільному волевиявленню, відкритий підкуп голосів виборців тощо. Місцеві вибори в Україні ускладнені також незавершеною адміністративно-територіальною реформою.

Актуальною і зараз $є$ думка ряду дослідників, що нормативно-правовий акт (який регулює організацію та проведення виборів - М.Л.) має абсолютно однозначно трактувати усі дозволи, заборони та обмеження в процесі підготовки та проведення виборчої кампанії, бо від цього значною мірою залежить наявність або відсутність таких негативних явищ як використання адміністративного ресурсу, підкуп виборців, нерівність можливостей інше. I саме в такому напрямку має вдосконалюватись виборче законодавство. I правотворчість, і правозастосування повинні відповідати головній меті - зробити вибори чесними, прозорими, демократичними [3].

Висновки. Таким чином, ключові проблеми місцевих виборів є наступними: 1) можливість та потреба перевірки даних, які подаються кандидатами для реєстрації; 2) процедура розподілу керівних посад у дільничних виборчих комісіях; 3) обрахування виборчої квоти та розподіл мандатів за пропорційною виборчою системою. Для парламентських та президентських виборів актуальною залишається проблема удосконалення виборчої системи 3 огляду на передовий європейський досвід. Спільними проблемами для всіх типів виборів в Україні залишаються питання оскарження різноманітних процедур виборчого процесу, а також невідворотності притягнення до адміністративної або кримінальної відповідальності порушників цього процесу. Для подальшого удосконалення виборчого законодавства, важливо, щоб Виборчий кодекс абсолютно однозначно визначав усі дозволи, заборони та обмеження в процесі підготовки й проведення виборчої кампанії. Від цього значною мірою залежить наявність або відсутність використання адміністративного ресурсу, підкупу виборців, нерівності можливостей суб’єктів виборчого процесу.

\section{ЛITEPATYPA}

1. Виборчий кодекс України: Закон України від 19 грудня 2019 р. № 396-IX / Верховна Рада України. URL: https://zakon.rada.gov.ua/ laws/show/396-20\#Техt (дата звернення: 10.07.2021).

2. Антонова Л.В., Антонов А.В. Удосконалення виборчого процесу в Україні: організаційно-правовий аспект. Електронне «Державне управління: удосконалення та розвиток». DOI: 10.32702/2307-2156-2020.12.2

3. Кормич А.І., Кормич Л.І. Специфріка виборчого процесу та особливості формування електорального простору сучасної України. Актуальні проблеми політики. 2013. Вип. 48. С. 23-29.

4. Стукаленко В.А. Сучасні актуальні проблеми виборчого процесу в Україні. Правова держава. 2017. № 27 С. 65 -70.

5. Постанова Центральної виборчої комісії від 21 серпня 2020 року № 192 Про Порядок розгляду скарг виборчими комісіями з виборів Президента України, народних депутатів України, місцевих виборів / Верховна Рада України. URL: https://zakon.rada.gov.ua/laws/show/ v0192359-20\#Text

6. Єдиний державний реєстр судових рішень. Рішення Чернігівського окружного адміністративного суду в справі № 620/4568/20 від 15 жовтня 2020 р. URL: https://reyestr.court.gov.ua/Review/92197687

7. Єдиний державний реєстр судових рішень. Рішення Одеського окружного адміністративного суду в справі № 420/10423/20 від 11 жовтня 2020 р. URL: https://reyestr.court.gov.ua/Review/92119171 